\title{
A Mediating Factor of Consumer Trust in ISO 9000 Implementation in Relation to Customer Satisfaction: A Study on Internal Perceptions of Indonesian Manufacturing Companies
}

\author{
Harianto Respati ${ }^{1}$, Surachman ${ }^{2}$, Djumilah Hadiwidjojo ${ }^{3}$, Djumahir ${ }^{4}$ \\ ${ }^{I}$ (Student of Economics and Business Faculty, University of Brawijaya, Indonesia) \\ 234 (Economics and Business Faculty, University of Brawijaya, Indonesia)
}

\begin{abstract}
The purpose of the current study is to examine the role consumer trust plays in accordance to the implementation of International Organisation for Standards (ISO) 9000 certification in order to achieve the ultimate goal of customer satisfaction. Consequently, three variables identified and measured in the study are: the implementation of ISO 9000 certification, costumer confidence, and customer satisfaction. As many as 115 ISO 9000-certified manufacturing companies in East Java, Indonesia, take part as the sample of the study. Data are collected through a survey. The respondents are management representatives from the companies. Structure analysis and inferential statistics are employed in data analysis process.

The study finds that consumer trust is able to mediate the role of ISO 9000 in increasing customer satisfaction level. Employees' effort in building up costumer confidence by providing accurate information has been proven an effective way in satisfying customers themselves.

Previous studies generally focus on investigating consumer trust and customer satisfaction based on the perceptions of the users of the products. This present study aims at investigating consumer trust and satisfaction level based on the perceptions of ISO 9000 implementers working in the manufacturing companies. Moreover, the novelty of the study lies in the testing of the effects of ISO 9000 implementation toward consumer trust.
\end{abstract}

Keywords - ISO 9000, Consumer trust, Customer satisfaction, Indonesian manufacturing companies

\section{Introduction}

The growth of international trade volume and high customer expectations on quality has played such a crucial role in elevating consumer trust towards quality through the enforcement of ISO 9000 (Bruce et al, 2007); this situation, as well as the execution of CAFTA 2010 which leads to the free trade era, has urged Indonesian manufacturing companies to improve the quality of their products and to maintain their customer satisfaction at the highest levels possible. The problem, as Tea (2008) argues, regarding to the implementation of ISO as a measuring scale of quality management - be it in relation to the quality of products, of health and workplace safety, and of environment - since the day it was adopted in Indonesia has been in the spirit of Indonesian companies which see ISO merely as a symbol of prestige. The adoption and the processes in the implementation of management quality standards (ISO) are superficial in nature - companies care much about their prestige than their quality. Many companies are confused about the real benefits of certification, even after they are certified ISO. In line with this fact, Corrigan (1994) and Johannsen (1995) state that the implementation of ISO certification results in static quality systems, increasing lines of bureaucracy, and decreasing both flexibility and innovations. Too many commands going down the chain may lead into weariness and boredom. Other critics argue that standardization does not guarantee efficiency.

The ineffectiveness of ISO 9000 in ensuring quality management systems in Indonesia, the challenges of CAFTA 2010, and the necessity of manufacturing sector to improve its performance have become the reasons for the researcher to investigate the roles ISO 9000 plays in advancing customer satisfaction of Indonesian manufacturing companies, especially in East Java Province.

Employees who apply ISO 9000 as their quality management system find it easier to understand the documentation system in ISO 9000 certification compared to product users or customers. Therefore, the research employs internal perception approaches by measuring the extent to which ISO 9000 is implemented from the point of views of the employees; in this sense, the employees of the manufacturing companies become the respondents of the study.

A study by Caro and Garcia (2009) examining the effects of ISO 9000 certification towards customer perceptions on satisfaction, quality, and corporate image of an insurance company in Spain shows that ISO 9000 certification can help to increase the customers' perception on satisfaction. The ultimate and main principle of ISO 9000 relates to customer satisfaction. Gotzamani and Tsiotras (2002), Pan's, (2003), Deming (1982), 
Wilkinson, et al. (1993), Anderson et al.(1994), Sun (2000) and Bruce et al. (2007) agree that the long term orientation of ISO 9000 certification is on customer satisfaction.

A rather different view, however, comes from the result of a study by Cadesus et al. (2001), which concludes that not all companies are able to take advantages from the implementation of ISO 9000 certification. Another study by Gotzamani and Theodorakioglou (2006) reveals that many companies have failed to achieve the ultimate goal of ISO 9000 due to low commitment on quality shown by the top management and to the superficial motivation in the adoption of the standards - that is only for prestige and acknowledgement. The results of studies which oppose the positive correlation between ISO 9000 and customer satisfaction shall become a good topic to investigate. The research question addressed then deals with the solution of the problem or effective ways for ISO 9000 to function as expected in increasing customer satisfaction levels.

Caro and Garcia (2009) suggest future researchers to analyse the effects of ISO 9000 implementation toward a more specific dimension of service and performance. As an example, it might be interesting to examine the relationship between ISO 9000 and consumer trust.

Consumer trust can help companies to build good long term relationship with the customers (Aurier et al., 2007) and to reduce uncertainties in companies (Srinivasan, 2004). It is important that companies trust the customers in the application of ISO 9000 in order to create higher level of customer satisfaction; this applies to manufacturing companies, as well. Thus, it is expected that employees running ISO 9000 documentation system are able to boost customer satisfaction through consumer trust. Regarding the importance of consumer trust, it is then treated as a mediating variable in this present study.

Different views exist on the concept of relationship between consumer trust and customer satisfaction. Geyskens et al. (1999) and Kennedy et al. (2001) believe that the relationship between those two factors is difficult to measure. Geyskens et al. (1998) argues that trust is an effective way to elevate satisfaction in long term orientation. A study by Brigne and Blesa (2003) examined and compared three models of relationship, namely the effect of trust on satisfaction, the effect of satisfaction on trust, and a non-recursive model between trust and satisfaction. The study was conducted towards distributors in Spain ceramic industry. The best model resulted from the study was that trust positively affected satisfaction. This study by Brigne and Blesa (2003) proves that trust can drive satisfaction as the result of companies' policy on long term market orientation.

Literature review on previous studies on ISO 9000 shows that the formula on how to best implement ISO 9000 in order to guarantee customer satisfaction is very limited. There have not been any studies either examining internal perceptions on the implementation of ISO 9000 in relation to customer satisfaction or placing consumer trust as a mediating factor in the implementation of ISO 9000 in relation to customer satisfaction. As such, the researcher intends to investigate consumer trust as a new formula for ISO 9000certified manufacturing companies in their effort to drive customer satisfaction. Addressing the deficiency in literature has been the final purpose of this study.

\section{The Implementation of ISO 9000}

\section{Literature Review}

Gaspersz (2002) defines ISO 9000 as an international standard for quality management systems having particular requirements and recommendations for the design and the assessment of quality management systems which aims is to ensure that organizations will only manufacture products based on the required standards. Rothery (2000) sees ISO 9000 as a documentation system of quality management. ISO 9000 introduces the concept of effectiveness through the documentation processes to guarantee that the processes are conducted in the best manner possible (ISO 9000, 2000). ISO 9000 standardization has its origin in the standardization system of military forces during World War II. In 1979, the British Standards Institute developed a standard quality management named BS 5750. In 1987, BS 5750 was revised and adopted under the name of ISO 9000 international standards version 1987 (Franceschini et al, 2006). Many parties criticized the implementation of ISO 9000:1987, which later caused its revision and that finally it became ISO 9000:1994 (Hanas and Luczak, 2002).

Since the implementation of ISO 9000, it has been widely acknowledged that ISO 9000 helps to increase customer satisfaction levels (Williams, 1997). ISO 9000:2008 book of guidance mentions that ISO 9000 standardization is adopted in order to raise customer satisfaction and that customers themselves are given a room to decide on what aspects should be included in the standardization requirements of products. ISO 9000 plays such a significant role in the existence and the life of a company that many companies adopt it.

Pan's study (2003) in four Asian countries reveals that one of the many benefits upon having ISO 9000 certification is that it is able to elevate customer satisfaction. Within this study on internal perceptions, ISO 9000 implementation is defined as acknowledgement given to companies running internationally accepted documentation systems, such as quality systems, document controlling, correction, and internal quality auditing. 


\section{Customer Satisfaction}

Customer satisfaction within the next ten years will become a focus in business strategy planning and crucial consideration in evaluation of growth of companies (Naumann et al., 2001). Mehra and Ranganathan (2008) elaborates that customer expectation can be fulfilled if companies perform continuous quality improvement-if not, customers will simply cut their subscription. The success of companies depends on their ability to continuously satisfy their customer basic needs and improve their quality as the main source of customer satisfaction (Brah et al., 2002; Zethaml, 1988; Parasuraman et al., 1988; Slater and Narver, 2000).

Companies unable to identify and respond their customer basic needs will only face an increasing number of unsatisfied costumers which means decreasing amount of profit and earning (Gurau and Ranchhod, 2002). Hunt (1977) explains that customer satisfaction is a part of emotion evaluation. Swan et al. (1998) defines customer satisfaction as conscious evaluation by companies dealing with product performance-does the product serve the purpose it is intended for? Rust and Oliver (1994) state that customer satisfaction is closely related to presentation of products to customers as to let them create such positive feeling of belonging or take advantages over the products offered. Thus, considering these all opinions, customer satisfaction within the framework of the present study is identified as employees' effort in shaping customers' positive perspectives through several approaches such as maintaining good reputation of their products, offering fair price, and keeping continuity of business transactions with customers.

\section{Consumer Trust}

Most studies in distribution system explain trust as an extent of certainty on honesty and goodness toward companies as a trading partner (Brigne and Blesa, 2003). Trust is very important in such uncertain environment; it determines the success and continuity of any business activities (Srinivasan, 2004). Trust is closely related and is considered identical to high levels of satisfaction (Jones and Sasser, 1995).

Morgan and Hunt (1994) identify customer trust as a situation where people feel certain about the integrity and truth told to consumers as a trading partner. Morgan and Hunt (1994) furthermore assure that consumer trust can generally be reflected in two manners: credibility and benevolence. Credibility refers to the abilities of companies to provide certain circumstances (Aurier et al., 2001), whereas benevolence is a part of the concern companies have on their consumers (Aurier et al., 2007). Srinivasan (2004) believes that trust can be examined from many facets, such as transaction, information, products, technology, and institution. Considering all these statements, consumer trust within the framework of the present study is identified as employees' effort in shaping customers' positive perspectives aided with existing documentation, by showing the company's abilities and concern toward their customers, and by giving accurate and reliable information to the customers as a trading partner in order to maintain the life of the company and customer satisfaction itself.

\section{Formulation Of Hypotheses}

Brown and Wiele (1995) conducted a study on 160 ISO 9000-certified companies. The results of their study show that ISO 9000 elevates customer satisfaction. This conclusion is extended and supported by William (1997) who positively views that standardisation assists customer satisfaction. Thus, many companies are motivated to adopt ISO 9000. Gotzamani and Tsiotras (2002) articulate a similar opinion-that companies are motivated to register for ISO 9000 since they want to promote customer satisfaction.

The results of the study by Pan's (2003) in four Asian countries expose the fact that ISO 9000 certification has helped many companies in term of increasing employees' competence in ensuring customer satisfaction; similar findings also come from a study by Caro and Garcia (2009) which reveals that ISO 9000 can enhance perception in satisfying customers, maintain quality, and improving corporate image. All of these studies show that ISO 9000 management quality is adopted and implemented by companies to serve an ultimate goal of customer satisfaction. H1. The implementation of ISO 9000 significantly affects customer satisfaction.

The implementation of ISO in the long run is projected toward maintaining customer satisfaction (e.g. Mehra et al., 2001; Gotzamani and Tsiotras, 2002; Pan's, 2003; Deming, 1982; Wilkinson et al., 1993; Anderson et al., 1994; Sun, 2000; Bruce et al., 2007). Caro and Garcia (2009) recommend future researchers to analyze the effects of ISO 9000 implementation toward consumer trust. The factor underlying their recommendation is the fact that trust is very crucial for companies to face uncertain circumstances and environment, not to mention to build long term relationship with their customers (Srinivasan, 2004). Geyskens et al. (1998) even state that trust is an effective way to improve customer satisfaction especially for companies having long term market orientation. The statement by Geyskens et al. (1998) is supported by the results of a study by Brigne and Blesa (2003) which concludes that trust affects customer satisfaction for manufacturing companies with long term market orientation.

Trust holds such a critical importance and value in the implementation of ISO 9000 in order for the companies to achieve their upmost objective - customer satisfaction. Thus, the second hypothesis of the current study is formulated as follows: 
H2. Consumer trust is able to mediate the implementation of ISO 9000 in order to elevate customer satisfaction.

\section{Design of the Study}

\section{Methodology}

Thus study employs survey as the method of data collection through questionnaires. Likert scale is used in the questionnaire. To answer the research problems, the approach used in this study is positivist quantitative. The relationship between latent variable and indicators is reflective. The exogenous variable of ISO implementation is reflected in four indicators, namely quality management application, document controlling, correction, and internal quality auditing. The endogenous variable of consumer trust is manifested in three indicators, namely abilities of companies, concern companies have on their customers, and information given by companies. Customer satisfaction as the other variable is elaborated in three indicators, namely product reputation, price suitability, and business transactions.

\section{Population}

The population of the study is all ISO 9000:20008-certified manufacturing companies in East Java Province, Indonesia. There are 243 large scale ISO-certified manufacturing companies; these companies have more than 100 employees and are listed in the data of Dinas Perindustrian dan Perdagangan of East Java Province, Indonesia. Employees having position as Management Representatives are the respondents of the study.

\section{Sampling}

Sample is generated from the population through a formula by Yamane (1973). There are 153 manufacturing companies chosen as the sample of the present study. Sample is selected through simple random sampling in which each manufacturing company has an equal chance to be taken as the sample of the study.

\section{Instrumentation}

\section{Result And Discussion}

Table 1 shows the result of validity and reliability tests of the research instrument. The Pearson Product Moment correlation coefficient for all research indicators fall above 0.3 at 0.001 level of significance-this means that the items on the questionnaire do measure what they intend to measure. The Cronbach Alpha value for each research variable fall above 0.6 - this means that items in the questionnaire are consistent or measure the same traits.

Table 1. Composite Validities and Reliabilities of Research Instrument

\begin{tabular}{lcc}
\hline \multicolumn{1}{c}{ Variable and Indicators } & $\begin{array}{c}\text { Product Moment } \\
\text { Correlation }\end{array}$ & Cronbach Alpha \\
\hline ISO 9000 & $0.646^{* *}$ & \\
Quality Management System (QMS) & $0.713^{* *}$ & 0.873 \\
Document Controlling (DC) & $0.642^{* *}$ & \\
Correction (CR) & $0.631^{* *}$ & \\
$\quad$ Internal Quality Auditing (IQA) & & \\
Consumer Trust & $0.741^{* *}$ & 0.826 \\
Ability (AB) & $0.702^{* *}$ & \\
Concern (CC) & $0.851^{* *}$ & \\
Information (IF) & & \\
Customer Satisfaction & $0.869^{* *}$ & 0.684 \\
Product Reputation (PR) & $0.663^{* *}$ & \\
Price Suitability (PS) & $0.545^{* *}$ &
\end{tabular}

Note $: \mathrm{n}=253$. All coefficients are significant at 0.001 level (when identified by $* *$ )

Figure 1 shows the summary of SEM analyses using AMOS. The loading factors of each latent variables show that all of them fall above 0.5 at significant level $<0.05$. This means that each of the latent variables can form uni-dimensionalities and meet the high convergent validity. The structural equity model (Figure 1) can be used as an analysis tool shown by the Chi-square value (233.36) divided with the degree of freedom (32) resulted in 1.209. 
The loading factors of each research indicator (Figure 1) such as management quality system, company information, and business transactions are higher than their latent variables of ISO 9000, consumer trust, and customer satisfaction.

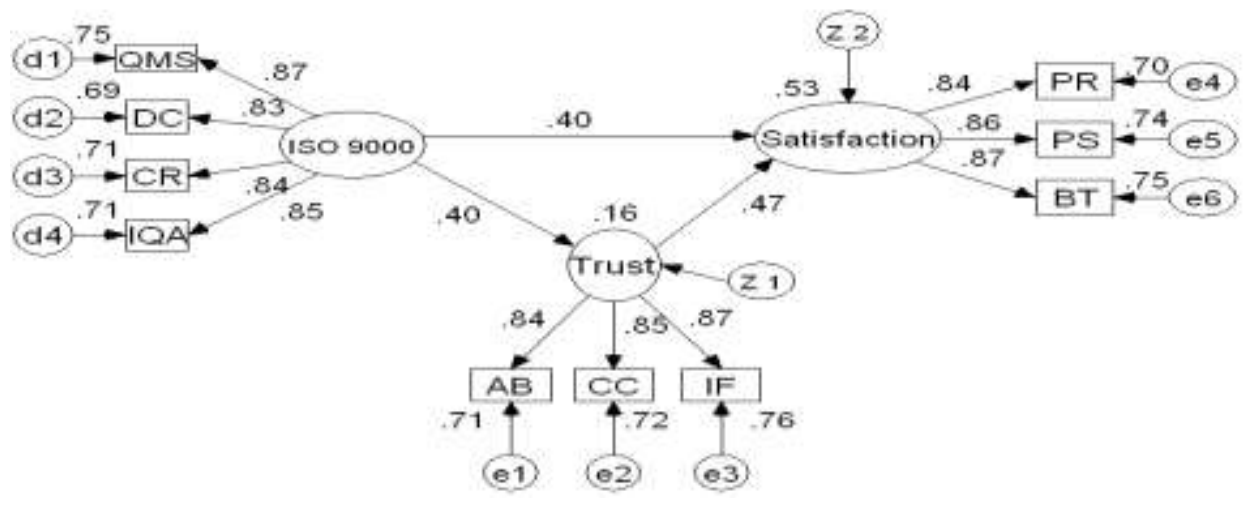

Figure 1 Output Measurement Model Using AMOS approach

Causality relationship among research variables is shown on Table 2. The result of the statistical analysis through structural equity model on direct effect of ISO 9000 toward customer satisfaction shows insignificant effect. Analyses on direct effect among other research variables show positive and significant relationship. Trust can partially mediate the direct effect of ISO 9000 toward customer satisfaction.

Table 2 Causality Relationship among Research Variables

\begin{tabular}{|c|c|c|c|c|c|c|}
\hline \multicolumn{3}{|c|}{ variables } & \multicolumn{3}{|c|}{ coefficients } & \multirow{2}{*}{ result } \\
\hline independent & Mediation & dependent & direct & indirect & total & \\
\hline ISO $9000 \rightarrow$ & - & Satisfaction & 0,400 & - & 0,031 & $\begin{array}{l}\text { H1 - } \\
\text { unsupported }\end{array}$ \\
\hline \multirow[t]{2}{*}{ ISO $9000 \rightarrow$} & Trust & - & $0,400 *$ & - & $0,400 *$ & - \\
\hline & Trust $\rightarrow$ & Satisfaction & $0,470^{*}$ & - & $0,470 *$ & - \\
\hline ISO $9000 \rightarrow$ & Trust $\rightarrow$ & Satisfaction & - & $\begin{array}{c}0,400 \mathrm{X} \\
0,470 \\
=0,188^{*}\end{array}$ & - & H2-supported \\
\hline
\end{tabular}

Note: All coefficients are significant at 0.05 level (when identified by *)

\section{Relationship of ISO 9000 with Customer Satisfaction}

The first hypothesis confirmation shows that the implementation of ISO 9000 significantly affects customer satisfaction (Table 2). This finding means that documentation system in ISO 9000 adopted by East Java manufacturing companies is not yet able to support the administration system of the companies to satisfy the customers. The finding is in line with the finding from a study by Bruce et al. (2007) in the USA and in line with Johannsen's statement (1995) saying that the implementation of ISO 9000 does not guarantee customer satisfaction.

The result of interviews with several key informants elaborates some factors why ISO could not guarantee customer satisfaction. This is caused by the ways documentation systems are conducted in many of the large scale manufacturing companies - in which the systems are not integrated amongst departments. Employees have to be able to serve customers effectively and efficiently - and integration in terms of documentation will help a lot in doing so. Therefore, large scale manufacturing companies need to be equipped with information technology to help supporting employees' administrative work, especially when it comes to customer satisfaction.

\section{Customer Trust Mediated the Implementation of ISO 9000 toward Customer Satisfaction}

The second hypothesis confirmation through structural equity model shows that ISO 9000 implementation significantly affects consumer trust, which means that the better the documentation systems are conducted, the more help the employees get in shaping customer trust. Companies' documentation systems guide the employees in shaping and building up consumer trust since the availability of organized 
documentation help employees a lot in giving true information about the quality of the products (see Figure 1 for loading factors). The result of the analysis supports Caro's and Carcia's recommendation (2009) about the importance of examining the effects of ISO 9000 standardization towards trust.

Another result from structural equity analysis shows that trust significantly affects customer satisfaction, which means when employees are able to show the true information from the documents to the customers, then the customers feel more satisfied; this can be seen from the activity of company business transactions which runs very well (see Figure 1 for loading factors). This finding supports the findings from the study by Brige and Blesa (2003) in Spain. Manufacturing companies in Spain posses some similarities with Indonesian large scale manufacturing companies in which both of them have long term market orientation for customer satisfaction.

The results of structural equity analyses show that trust is able to mediate the implementation of ISO 9000 in elevating customer satisfaction; this means that trust can be an effective strategy for ISO 9000-certifed manufacturing companies to finally come to their final goal: customer satisfaction.

The advantages of ISO 9000 need to be socialized to Indonesian people as users of products and customers. Trust is completely important for the life of companies and for the secure feeling of costumers when they use the products.

\section{Conclusions And Further Research}

The documentation systems of ISO 9000 in large scale manufacturing companies are not directly able to help the administrative work of the employees in satisfying customers; as such, it needs to be confirmed by another relevant mediating factor. The abilities of employees in ensuring their customers by giving true information is determined by the success of ISO 9000 documentation systems in large scale manufacturing companies.

Gotzamani and Theodorakioglou (2006) explain that strong commitment from top management are needed in the process of shaping and building up customer satisfaction, since it empowers quality as the main strategy to win competition. The findings from the study by Gotzamani and Theodorakioglou (2006) reveal that many companies fail to achieve the goals of ISO 9000 standardization, due to low commitment of top management to quality and due to the fact that the main motivation behind standardization is merely for the companies to get acknowledgement. Dauglas et al. (1999) believes that companies will get more advantages upon ISO 9000 implementation when there is good and appropriate internal motivation. A study by Gustafsson et al. (2001) in Sweden manufacturing companies find several key factors for the success of ISO 9000 implementation; and that deals a lot with internal motivation of the companies to improve quality. The failure of ISO 9000 implementation is caused by the existence of external motivation-in which companies think more about prestige, but not quality to satisfy their customers.

Referring to all the results of those previous studies, it may be interesting for future researchers to examine quality management and company culture as a mediating factor in the implementation of ISO 9000 in order to drive customer satisfaction.

\section{Limitations}

This study is conducted using a perception method in measuring the observed variables which may cause bias toward the results of the measurement. There is only one respondent participating in each unit of analysis which may lead to high level of mono response bias. The analysis units in this study do not focus on one particular industry, and that has made this study unable to give a comprehensive picture of manufacturing companies adopted ISO 9000.

\section{Notes On First Contributor}

Harianto Respati is a Lecturer in Management Department at the Faculty of Economics, Merdeka University, Malang, Indonesia. His research interests are in Quality, Information Technology, Operational Management and Marketing.

\section{REFERENCES}

[1] Anderson, J.C., Rungtusanatham, M. and Schoeder, R.G. A theory of quality management underlying the Deming management method, Academy of Management Review, Vol.19 No.3, 1994, pp. 472-509

[2] Aurier, P. and Martin, B.S, Perceive justice and consumption experience evaluations, International Journal of Service Indutri Management, Vol.18. No.5, 2007.

[3] Aurier, P., Benavent, C., and N'Goala, G., Validite discriminante et predictive des composantees de la relational a la marque, paper presented to International Annual Conference of French Marketing Association. Deauville, available at: www.afm-marketig.org., 2001.

[4] Brah, S. A., Tee, S. L., and Rao, B. M, Relation between TQM and performance of Singapore companies. International Journal of Quality and Reliability Management 19 (4), 2002,356-379 
[5] Brigne, E. and Blesa, A, Market orientation, trust and satisfaction in dyadic relationship: a manufacturer-retailer analysis. International Journal of Retail \& Distribution Management, Vol. 31 Nov. 11, 2003,574-590.

[6] Brown, A. and van der Wiele, T, Industry experience with ISO 9000, Asia Pacific Journal of Quality Management Vol.4 No.2, 1995, pp. 8-17

[7] Bruce S., Han, Shaw K. Chen, Maling Ebrahimpour, The impact of ISO 9000 and TQM and Business performance. Journal of Business and Economic Studies, Vol. 12 NO.2, 2007.

[8] Casadesus, F.M., Gimenez, G., and Heras, S.L, Benefits of ISO 9000 implementation in Spanish industry. European Business Review, Vol.13 No.6, 2001, pp.327-35

[9] Caro, Laura Martinez. and Garcia, Jose Antonio, Does ISO 9000 certification affect consumer perception of the service provider?. Managing Service Quality .Vol.19 No.2, 2009, pp. 140-161.

[10] Corrigan, J, Is ISO 9000 the path to TQM?. Quality Progress. May, 1994, pp.33-6

[11] Douglas, A., Lirk, D., Brennan, C., and Ingram, A, Maximizing the benefits of ISO 9000 implementation. Total Quality Management 10 (4-5), 1999, 507-513.

[12] Deming, W.E, Out of the Crisis, (MIT Press. Cambridge,MA, 1986).

[13] Franceschini, F., Galetto, M., and Cecconi, P, A worldwide analysis of ISO 9000 standard diffusion, Consideration and future development' Bechmarking, An International Journal, Vol.13 No.4, 2006, pp. 523-41

[14] Gaspersz, Vincent, Pedoman implementasi program six sigma terintegrasi dengan ISO 9001:2000, MBNQA and HACCP,(Jakarta, PT Gramedia Pustaka Utama, 2002).

[15] Geykens, I., ,Steenkamp, J. B. E. M. and Kumar, N,. A-meta-analysis of satisfaction in marketing channel relationship. Journal of Marketing Research, Vol. 36 No.2, 1999, pp.223-38.

[16] Gotzamani, K. D., and Theodorakioglou Y. D, A longitudinal of the ISO 9000:1994 series' contibution toward TQM in Greek industry, The TQM Magazine. Vol. 18 No.1, 2006, pp.44-54

[17] Gotzamani, K. D., and Tsiotras, G,The true motives behind ISO 9000 certification. International Journal of Quality \& Reliability Management,. Vol..19 No.2, 2002.,pp. 151-69

[18] Gurau, C. and Ranchhod, A, How to calculate the value of a customer, Journal of Targeting Measurement and Analysis for Marketing, Vol. 10 No. 3, 2002, pp.120-220

[19] Hanas, I. and Luczak, H, Explorative study of expected consequences for existing quality management system due to the revision of ISO 9001 in certified companies in Germany, The TQM Magazine. Vol.14 No.2, 2002,pp. 127-32

[20] Hunt, H. K, CS/D - Overview and future research direction, in Hunt, H.K. (Ed.), Conceptualisation and Measurement of Customer Satisfaction and Dissatisfaction. Marketing Science Institute. Cambridge, MA, 1977, pp. 92-119.

[21] ISO 9000:2000, Quality Management System, (Fundamentals and Vocabulary International Organization for Standardization, Geneva, 2000)

[22] ISO 9001:2008, Quality management system-requirement, (International Standard, Fourth edition, 2008).

[23] Johannsen, C. G, Application of the ISO 9000 standards of quality management in professional services: an information sector case, Total Quality Management. Vol.6 No.3, 1995, pp. 231-42

[24] Jones, T. O., and Sasser, W. E., Jr, Why satisfied customer defect. Harvard Business Review, Vol. 73, 1995, pp. 88-101.

[25] Kennedy, M.S., Ferell, K. K., and Le Clair, D. T, Customer's trust of salesperson and manufacturer: an empirical study. Journal of Business Research, Vol. 51. No. 1, 2001. pp. 73-86.

[26] Mehra S., and Ranganathan S, Implementing total quality management with a focus on enhancing customer satisfaction, International Journal of Quality \& Reliability Management. Vol.25. No.9, 2008, pp. 913-927

[27] Mehra, S., Hoffman., J. M., and Sirias, D, TQM as a management strategy for the next millennia, International Journal of Operations and Production Management, Vo. 21 No. 5/6, 2001,pp.855-76

[28] Moorman, C., Deshpdane, R., and Zaltman, G, Factors affecting trust in market research relationship. Journal of Marketing, Vol. 57,January, 1993, pp. 81-101.

[29] Morgan, R. M., and Hunt, S. D, The commitment-trust theory of relationship marketing, Journal of Marketing, Vol. 58 No.3, 1994, pp. 20-38.

[30] Naumann, S., Jackson, D. W. Jr., and Rosenbaum, M. S, How to implement a customer satisfaction program. Business Horizon. Vol. 44 No.1, 2001, pp. 37-46

[31] Pan, J. N, A comparative study on motivation for experience with ISO 9000 and ISO 14000 certification among far eastern countries, Industrial Management \& Data Systems, Vol. 103 No.8, 2003, pp.564-78

[32] Parasuraman, A., Zeitham, V. A., and Berry, L. L, SERVQUAL: a multiple-ite, scale for measuring consumer perceptions of service quality, Journal of Retailing, Vol.64 No.1, 1988, pp. 12-40.

[33] Rothery, Brian, ISO 9000 \& ISO 14000 untuk Industri Jasa, (Edisi terjemahan, Seri manajemen operasional NO.3 PPM, Jakarta, Pustaka Binaman Pressindo, 2000).

[34] Rust, R, and Oliver, R, Service quality: Insight and managerial implication from the frontier, in Rust, R. and Oliver, R. (Eds). Service Quality. New Directions in Theory and Practice, Sage, New York, NY, 1994, pp. 1-19

[35] Slater, S. F., and Naver, J. C, Intelligence generation and superior customer value, Journal of the Academy of Marketing Science. Vol 28. No.1, 2000,pp 120-137

[36] Srinivasan, S, Role of trust in e-business success, Information Management \& Computer Security, Vol. 12 No.1, 2004, pp. 66-72

[37] Sun, H, Total quality management, ISO 9000 certification and performance improvement. International Journal of Quality \& Reliability Management, Vol.17 No.2, 2000, pp.168-79

[38] Swan, J.E and M.R Bower, Service Quality and Satisfaction: The Process of People Doing Thing Together. Journal of Service Marketing. Vol. 12, No.1, 1998, pp 59-72

[39] Tea, Cep Ebet, Pembudayaan perilaku sistem. Directory ISO Certified Organization. (Sucofindo Magazine. 2008, pp.29)

[40] Tracey, M. A, Logistics/purchasing effectiveness, manufacturing flexibility and firm performance: instrument development and causal model analysis, Unpublished Dissertation. The University of Toledo, OH.1996.

[41] Wilkinson, A., Redman, T., and Snape, E., E, Quality management and Manager: An Institute of Management Report. (Corby Institute of Management, 1993).

[42] Williams, N, ISO 9000 as a route to TQM in small to medium sized enterprises: snake or ladder?, The TQM Magazine, Vol.9 No.1, 1997,pp.8-13

[43] Yamane, Taro, Statistic an Introductory Analysis, (Third Edition. Aoyama Gakuin University, 1973).

[44] Zeithaml, V.A, Consumer perceptions of price, quality and value a means: a means-end model and synthesis of evidence. Journal of Marketing, Vol. 52 No.3, 1988, pp. 2-22. 